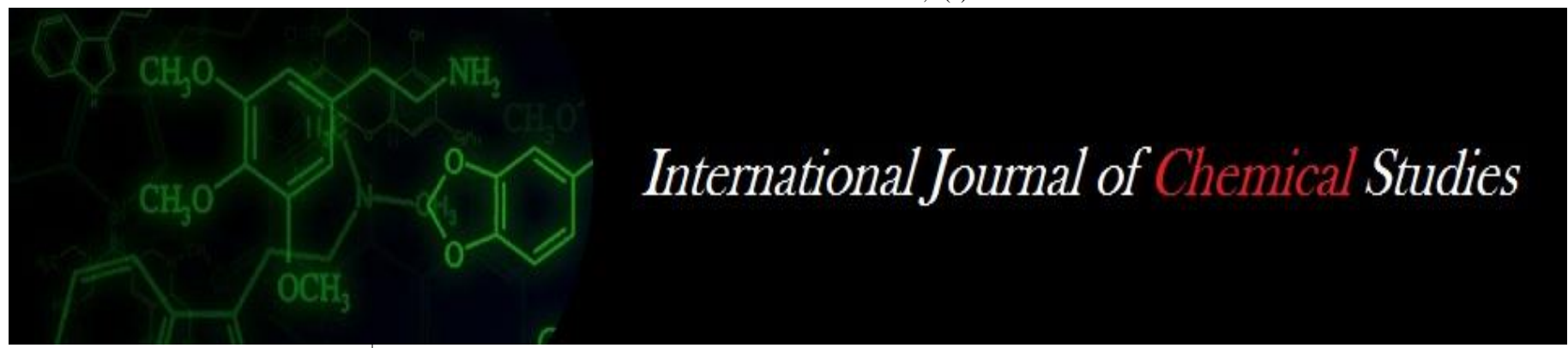

P-ISSN: 2349-8528

E-ISSN: 2321-4902

www.chemijournal.com

IJCS 2021; 9(1): 369-372

(C) 2021 IJCS

Received: 27-10-2020

Accepted: 15-12-2020

\section{Kashish Walia}

Department of Environmental

Science, College of Forestry,

YSP University of Horticulture

and Forestry, Solan,

Himachal Pradesh, India

\section{SK Bhardwaj}

Department of Environmental

Science, College of Forestry,

YSP University of Horticulture

and Forestry, Solan,

Himachal Pradesh, India
Corresponding Author:

Kashish Walia

Department of Environmental

Science, College of Forestry,

YSP University of Horticulture

and Forestry, Solan,

Himachal Pradesh, India

\section{Study of seasonal and spatial variations in leaf dust accumulation of selected tree species in the industrial area of Solan District of Himachal Pradesh}

\author{
Kashish Walia and SK Bhardwaj
}

DOI: https://doi.org/10.22271/chemi.2021.v9.i1e.11257

\begin{abstract}
The total dust load of the tree species namely Azadirachta indica, Dalbergia sissoo and Leucaena leucocephala in the industrial area of Baddi was recorded during summers, monsoon and winters and at different distances from the industrial cluster. The dust load of selected tree species ranged from 0.018$0.045 \mathrm{~g} \mathrm{~m}^{-2}$. The highest dust load was recorded in L. leucocephala followed by D. sissoo and A. indica. Seasonally the highest dust accumulation was recorded in winters $\left(0.057 \mathrm{~g} \mathrm{~m}^{-2}\right)$ and minimum in rainy season $\left(0.013 \mathrm{~g} \mathrm{~m}^{-2}\right)$. Within distances the decrease in the leaf dust accumulation with increasing distance from the industries was also observed which ranged from $0.013-0.041 \mathrm{mg} \mathrm{g}^{-2}$.
\end{abstract}

Keywords: Dust accumulation, Azadirachta indica, Dalbergia sissoo and Leucaena leucocephala

\section{Introduction}

Industries play a major role in the economic growth and development of a region but along with this growth and upliftment industrialization brings along numerous threats to our environment. So it must not be surprising that along with growth, industrialization brings in various pollutants which deteriorate the quality of our natural environment. Air pollution is one such undebatable problem caused due to rapid urbanization and industrialization, since it can affect all the dimensions of urban life. The dust generated through various industrial activities pose a serious threat to the biotic components of the environment. Since plants are an integral basis for all ecosystems and also most likely to be affected by air borne pollution (Rao, 1983) ${ }^{[8]}$. The effects are also most often apparent on the leaves which are usually the most abundant and most obvious primary receptors of large number of air pollutants.

Immense quantity of dust particles are released in to the atmosphere from vehicular activities, traffic congestion and activities concerned with manufacturing or processing and supplying and distribution of commodities usually on a large scale. These activities causes dust particle to adhere to the upper and lower surface of the leaves of various trees depending upon the wind velocity and the surface area of deposition (Das, 1980) ${ }^{[1]}$. These dust particles remain deposited to the leaf surfaces till they are washed off through precipitation. Besides, the airborne particulate matter commonly known as dust, also referred to Respirable Suspended Particulate Matter (RSPM) is also one of the major constituents of air pollution, which plays an important role in man-environment relationship. The accumulation of dust on plants leaves influence the leaf morphology, biochemical characteristics and exerts stress on plant physiology. Emissions from automobiles and trucks operating on public roads represent a major portion of the air pollutants included in the emission inventories. Agricultural and vehicular activities may generate dust which exceeds environmental guideline value and its deposition affects the physiology of plants (Manins et al., 2001) ${ }^{[4]}$. Dust capturing capacity of plants depends on their surface geometry, phyllotaxy and characteristics such as hair, cuticle, height and canopy of tree. Removal of pollutants by plants from air is by three means namely absorption by the leaves, deposition of particulates and aerosols over leaf surface (Rawat and Banerjee 1996) ${ }^{[9]}$. As leaf is the most sensitive part to the air pollutants thus plants experience physiological changes before exhibiting visible damage on leaves. Injury on plants due to air pollution ranges from visible markings on the foliage, reduced growth and yield to premature 
death of the plant. The pollutants can cause a serious threat to the overall physiology of plants. Very fine dust particle clogs the stomatal pores and even get deposited in to sub-stomatal cavities and pose physical and chemical effects like blocking stomata, lowers conductance to $\mathrm{CO}_{2}$ and leaf chlorosis (Shukla et al., 2019) ${ }^{[10]}$.

The seasons of the years by impacting atmospheric deposition, interception and the variation in weather parameters influence dust accumulation and biochemical concentrations in plant leaves. The response of plants to air pollution at physiological and biochemical levels can be understood by analyzing the factor that determine resistance and susceptibility. Using plants, as indicator of air pollution is the possibility of synergistic action of pollutants. Air pollutants are known to affect the plant growth. Various changes with respect to morphology and anatomy are induced by air pollutants in plants. Acclimatization of plants to air pollutants might change their morphological structure such as thicker epidermal cells and longer trichomes (Rangkuti, 2003) [7]. Plants are very sensitive to both gaseous and particulate pollutants and can be used as a bio indicator for monitoring atmospheric pollution Since plants provide an enormous leaf area for impingement, absorption and accumulation of air pollutants and decreases the pollutant level in the environment (Escobedo et al., 2008) ${ }^{[2]}$.

\section{Materials and Methods \\ Study area}

Baddi is an industrial town and a Nagar parishad in the southwestern Solan district of Himachal Pradesh. The town lies on the border of Himachal Pradesh and Haryana states in the foothills of Shiwalik range, around 35 kilometers west of Solan town. A detailed survey was conducted in the industrial area of Baddi to study the distribution of industries and vegetation in the region. Keeping in view the distribution of industries in the region five distances from $(0-100 \mathrm{~m}),(100-$ $200 \mathrm{~m}),(200-400 \mathrm{~m}),(400-800 \mathrm{~m}),(>800 \mathrm{~m})$ from the industrial cluster were selected. To compare the effect at different distances the distance of more than $800 \mathrm{~m}$ with less transportation, development and low industrial activity was considered as control. At each distance the commonly occurring plant species namely Azadirachta indica, Dalbergia sissoo and Leucaena leucocephala were selected and the data was recorded in summer (March-April), monsoon (JulyAugust) and winter (November-December) respectively. The leaf dust accumulation capacity of selected tree species and there correlation with different physiological and biochemical parameters like ascorbic acid, total chlorophyll content, leaf extract $\mathrm{pH}$ and relative water content was evaluated. The data recorded was analyzed by RBD (Factorial).

\section{Climate and weather conditions}

Baddi has a subtropical climate with four main seasons, the winter season commences from November to February and ends in March; summer season extends from March to June followed by the monsoon period extending from July to September. Average rainfall in the district is about $1150 \mathrm{~mm}$. The summers are hot and dry while the winters are dry and wet. The mean temperature ranges from $4{ }^{\circ} \mathrm{C}$ (during winter) and $42{ }^{\circ} \mathrm{C}$ (during summer).

\section{Sampling of leaves and dust}

To record the total dust load fully mature leaves of the selected plant species were taken for the present studies. The upper surfaces of the leaves were cleaned with fine brush and identification marks was put on them. These leaves were kept for 24 hours for dust accumulation and were collected in the pre weighed butter paper bags with the help of fine brush. After taking the data for dust accumulation, the leaves were cut from petiole, kept in ice box and brought to the laboratory for further analysis. The individual leaf $\left(\mathrm{m}^{2}\right)$ was measured with Leaf area meter (Model-LI-COR-3100). The samples were weighed using top pan electronic balance and the amount of dust was calculated using the following equation $\mathrm{W}=(\mathrm{w} 2-\mathrm{w} 1) / \mathrm{a}$, Where $\mathrm{w}$ is dust content $\left(\mathrm{g} \mathrm{m}^{-2}\right)$, w1 is initial weight of butter paper bag, w2 is final weight of butter paper bag with dust and a is total area of the leaf (m2).

\section{Result and discussion Dust deposition}

The present study showed that there is variation in the pattern of dust accumulated on leaves of different trees in different seasons and at different distances. The selected trees namely A. indica, L. leucocephala and D. sissoo growing in industrial area of Baddi varied in dust accumulation load on their leaves which ranged from $0.018-0.045 \mathrm{~g} \mathrm{~m}^{-2}$. The order of accumulation of dust on leaves of trees was L. leucocephala> D. sissoo $>$ A. Indica (Table 1). The highest dust accumulation on the leaves of L. leucocephala $\left(0.045 \mathrm{~g} \mathrm{~m}^{-2}\right)$ as compared to other species may be ascribed due larger leaf size, more folds, small petioles of the species and their ovate shape. Relatively, less dust accumulation on leaves of D. sissoo $\left(0.011 \mathrm{~g} \mathrm{~m}^{-2}\right)$ may be due to waxy coating on leaves and small petioles that might have reduced the movement of leaves in wind. Whereas, lowest dust load on A. indica $\left(0.018 \mathrm{~g} \mathrm{~m}^{-2}\right)$ may be due to long petioles that help the leaves to flutter during wind, surface smoothness and their waxy coating on the leaves. These findings are in conformity with the results of Vora and Bhatnagar (1986) ${ }^{[12]}$ and Garg et al. (2000) ${ }^{[3]}$ who have also reported role of leaf morphological characteristics in dust accumulation on their surfaces.

The leaf dust accumulation of the selected tree species growing in industrial area also varied with seasons which ranged from $0.013-0.057 \mathrm{~g} \mathrm{~m}^{-2}$.

Table 1: Seasonal variation in leaf dust accumulation $\left(\mathrm{gm}^{-2}\right)$ of tree species growing at different distances $(\mathrm{m})$ in industrial area

\begin{tabular}{|c|c|c|c|c|c|c|c|c|c|c|c|c|c|c|c|c|}
\hline \multirow[b]{3}{*}{$\begin{array}{c}\text { Distance/Spe } \\
\text { cies }\end{array}$} & \multicolumn{12}{|c|}{ Season } & \multirow{3}{*}{$\begin{array}{c}\text { Azadirac } \\
\text { hta } \\
\text { indica }\end{array}$} & \multirow{3}{*}{\begin{tabular}{|c|} 
Dalberg \\
ia \\
sissoo
\end{tabular}} & \multirow{3}{*}{$\begin{array}{c}\text { Leucae } \\
\text { na } \\
\text { leucoce } \\
\text { phala }\end{array}$} & \multirow[b]{3}{*}{$\begin{array}{c}\text { Mea } \\
\text { n }\end{array}$} \\
\hline & \multicolumn{3}{|c|}{ Rainy } & \multicolumn{4}{|c|}{ Winter } & \multicolumn{4}{|c|}{ Summer } & \multirow[b]{2}{*}{ Mean } & & & & \\
\hline & $\begin{array}{c}\text { Azadirac } \\
\text { hta } \\
\text { indica }\end{array}$ & \begin{tabular}{|c|} 
Dalberg \\
ia \\
Sissoo
\end{tabular} & $\begin{array}{c}\text { Leucaena } \\
\text { leucoceph } \\
\text { ala }\end{array}$ & Mean & $\begin{array}{c}\text { Azadirac } \\
\text { hta } \\
\text { indica }\end{array}$ & $\begin{array}{c}\text { Dalberg } \\
\text { ia } \\
\text { sissoo }\end{array}$ & $\begin{array}{c}\text { Leucaena } \\
\text { leucoceph } \\
\text { ala }\end{array}$ & Mean & $\begin{array}{c}\text { Azadira } \\
\text { chta } \\
\text { indica }\end{array}$ & $\begin{array}{l}\text { Dalberg } \\
\text { ia sissoo }\end{array}$ & \begin{tabular}{|c} 
Leucaena \\
leucoceph \\
ala
\end{tabular} & & & & & \\
\hline $0-100$ & 0.004 & 0.020 & 0.026 & 0.017 & 0.046 & 0.076 & 0.085 & 0.069 & 0.023 & 0.045 & 0.047 & 0.038 & 0.024 & 0.047 & 0.053 & 0.041 \\
\hline $100-200$ & 0.004 & 0.023 & 0.023 & 0.017 & 0.045 & 0.076 & 0.084 & 0.068 & 0.023 & 0.039 & 0.040 & 0.034 & 0.024 & 0.046 & 0.049 & 0.04 \\
\hline $200-400$ & 0.003 & 0.019 & 0.024 & 0.015 & 0.036 & 0.070 & 0.085 & 0.064 & 0.024 & 0.037 & 0.038 & 0.033 & 0.021 & 0.042 & 0.049 & 0.037 \\
\hline $400-800$ & 0.002 & 0.017 & 0.022 & 0.014 & 0.029 & 0.065 & 0.074 & 0.056 & 0.018 & 0.033 & 0.038 & 0.029 & 0.016 & 0.038 & 0.045 & 0.033 \\
\hline$>800$ & 0.001 & 0.005 & 0.006 & 0.004 & 0.004 & 0.008 & 0.068 & 0.027 & 0.006 & 0.007 & 0.009 & 0.007 & 0.004 & 0.007 & 0.027 & 0.013 \\
\hline Mean & 0.003 & 0.017 & 0.02 & 0.013 & 0.032 & 0.059 & 0.079 & 0.057 & 0.018 & 0.032 & 0.034 & 0.028 & 0.018 & 0.036 & 0.045 & \\
\hline
\end{tabular}

$\mathrm{CD}_{0.05}$ Species

Species $\times$ Season 


$\begin{array}{ll}\text { Species } \times \text { Distance } & : 0.002 \\ \text { Season } \times \text { Distance } & : 0.002 \\ \text { Species } \times \text { Season } \times \text { Distance } & : 0.003\end{array}$

The season wise leaf dust load of selected tree species was in order of winter $>$ summer $>$ rainy (Table 1, Fig. 1, 2, 3). The higher dust load during winters on leaves may be due to relatively less washing of dust from the leave because of fewer rains during the season. This is in agreement with the findings of Prajapati and Tripathi (2008) [5] who while studying seasonal variation of leaf dust accumulation and pigment content in tree species exposed to urban environment reported highest dust accumulation in winter followed by summer and rainy season. Prusty et al. (2003) ${ }^{[6]}$ also revealed seasonal variation of dust accumulation in vegetation near the national highway at Sambalpur in Orissa, India.

The leaf dust load of the selected tree species growing in Baddi industrial area also varied with different distances which ranged from 0.013 to $0.041 \mathrm{~g} \mathrm{~m}^{-2}$.Trees growing at different distances in the industrial area contained leaf dust load in the order $0-100>100-200>200-400>400-800>$ 800 (control). The highest content of $0.053 \mathrm{~g} \mathrm{~m}^{-2}$ in leaf dust of selected tree species at a distance of $0-100$ might be due to high industrial activities. The results are in conformity with the findings of Spatt and Miller (1981) ${ }^{[11]}$ who also reported that the dust arising from vehicular traffic settled in greatest quantities near the road with the amount rapidly decreasing away from the road. The species $\times$ season interaction irrespective of sites influenced the dust load in the leaves of the selected trees which ranged from $0.003-0.079 \mathrm{mg} \mathrm{kg}^{-1}$ and was highest in L. leucocephala during winter and minimum in $A$. indica in rainy season. The species $\times$ site interaction also influenced the leaf dust load in the leaves of the selected trees growing in and around industrial area. The highest leaf dust load was in L. leucocephala at 0-100 m, whereas minimum was in A. indica at $>800 \mathrm{~m}$ control (non-polluted site). The trees growing at $0-100 \mathrm{~m}$ distance contained higher dust load in the leaves of selected tree species during winter season whereas, those growing at control area contained minimum amount of dust load during rainy season. Maximum leaf dust load was in case of L. leucocephala growing at 0-100 m distance during winter season whereas, minimum was in $A$. India at control area during rainy season.

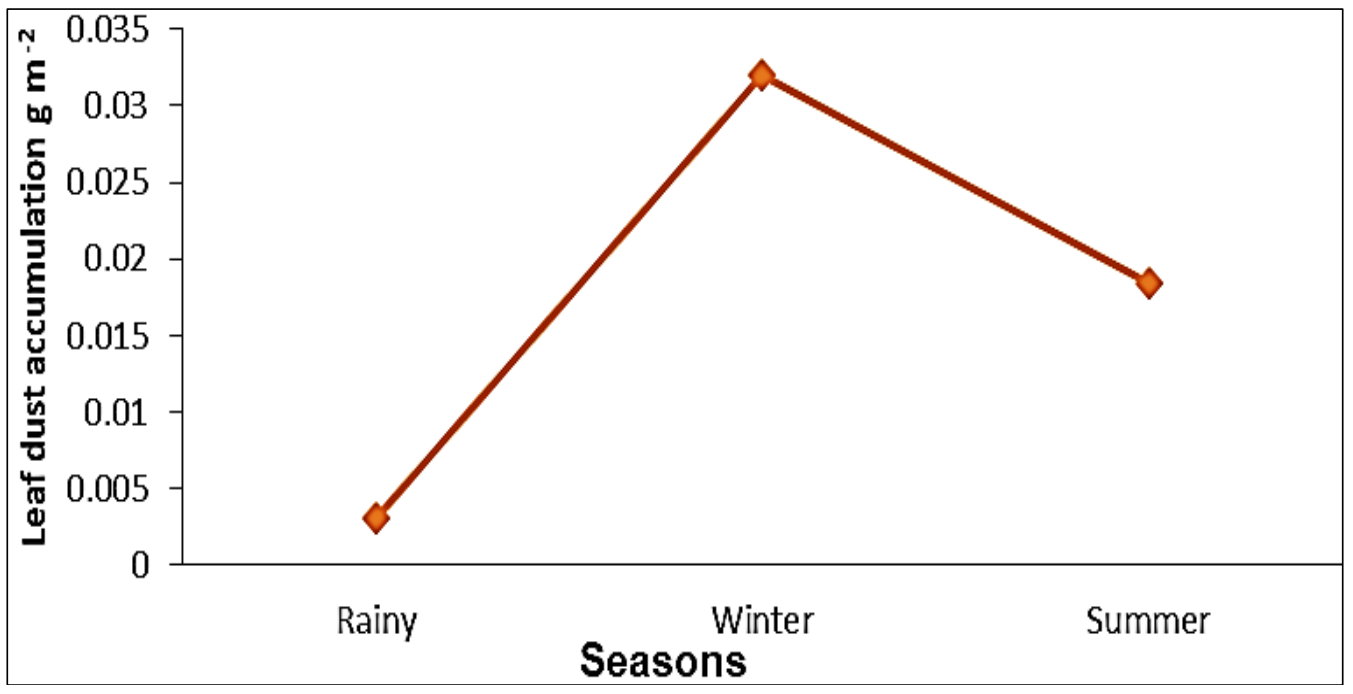

Fig 1: Seasonal variation in leaf dust accumulation in Azadirachta indica

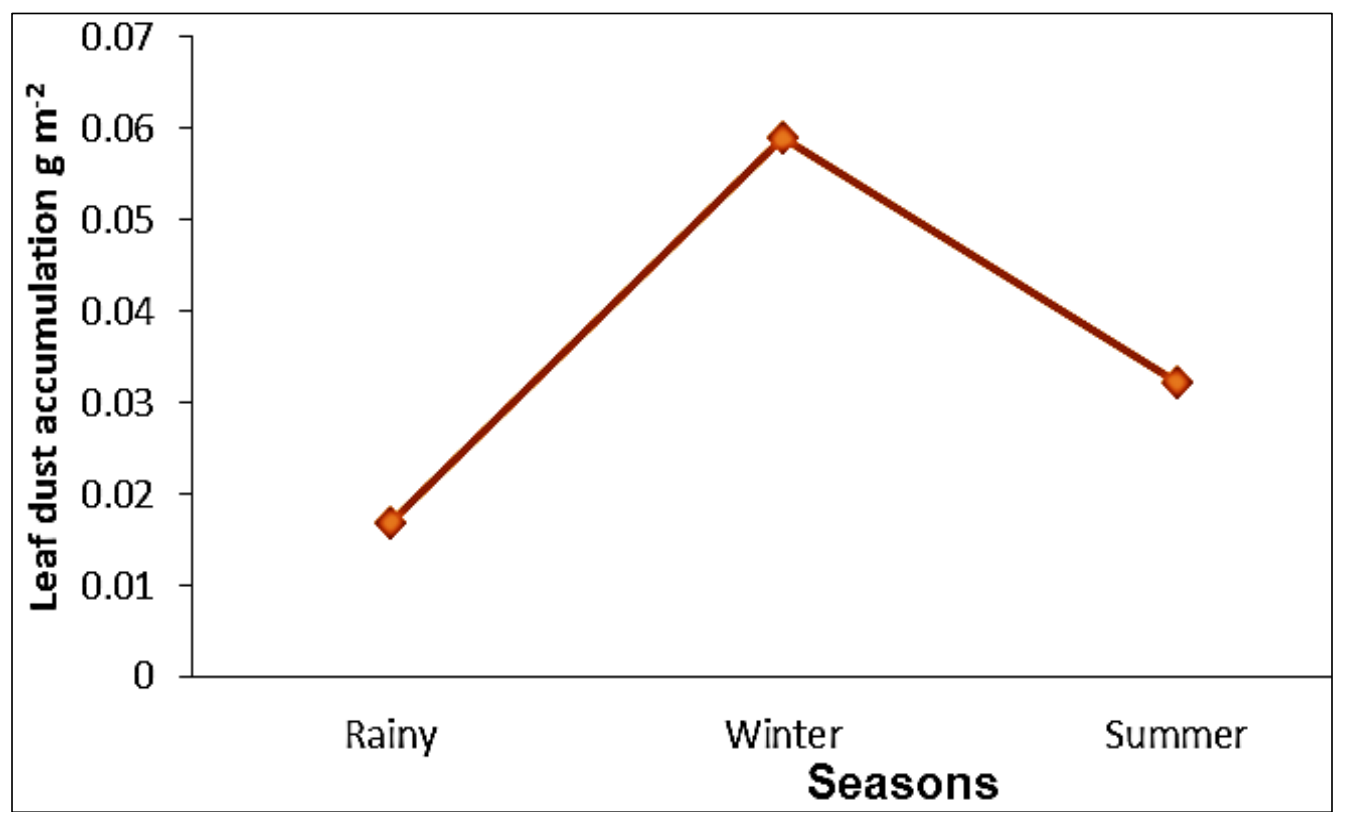

Fig 2: Seasonal variation in leaf dust accumulation in Dalbergia sissoo 


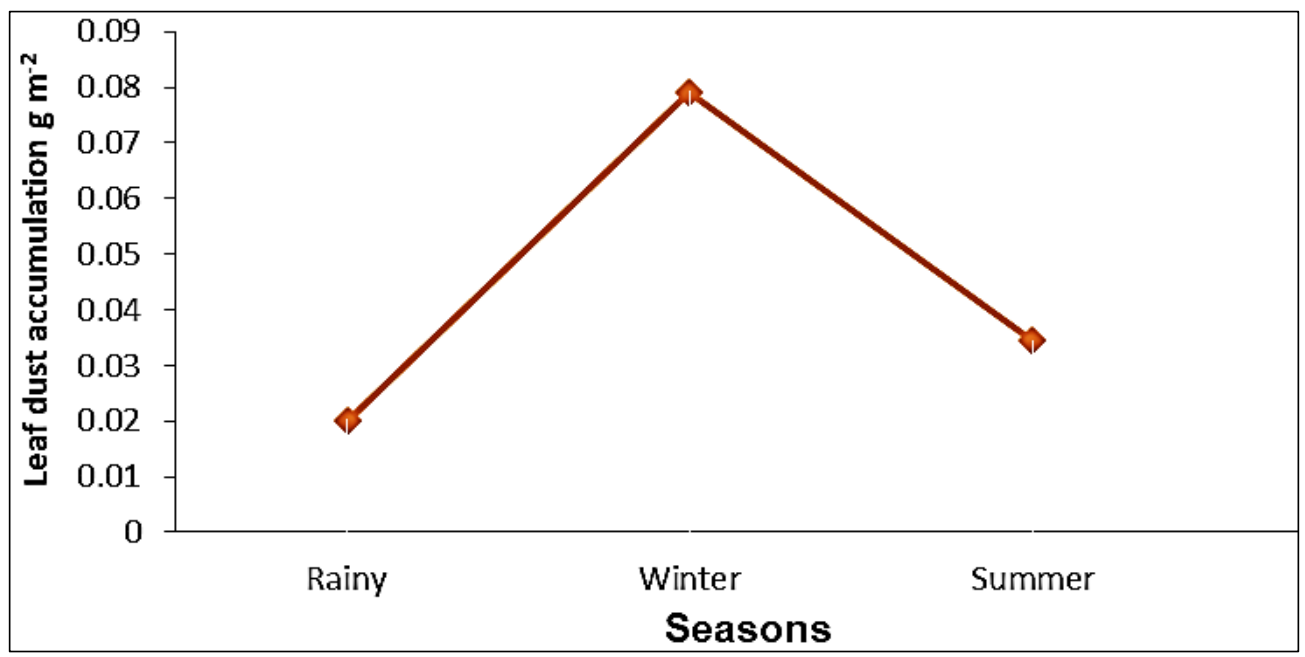

Fig 3: Seasonal variation in leaf dust accumulation in Leucaena leucocephala

\section{Conclusion}

The dust load of selected tree species growing in the industrial area of Baddi ranged from $0.018-0.045 \mathrm{~g} \mathrm{~m}^{-2}$ and the order was L. leucocephala $>D$. sissoo $>A$. indica. The season wise variation in dust accumulation was $0.013-0.057 \mathrm{~g} \mathrm{~m}^{-2}$ and was in order of winter $>$ summer $>$ rainy. Within distances dust load accumulation on the leaves of selected trees ranged from $0.013-0.041 \mathrm{mg} \mathrm{g}^{-2}$, which was in the order 0-100>100-200 > 200-400 > 400-800 > control.

\section{Acknowledgment}

The facilities provided by the Department of Environment Science, YSP University of Horticulture \& Forestry, Nauni, Solan (HP) India are highly acknowledged.

\section{References}

1. Das TM. Monitoring and Control of Air Pollutants through Plants. In: Recent Research in Ecology and Pollution, Ray M et al. (Eds.). Today's and Tomorrow's Printers and Publishers, India, 1980, 143-151.

2. Escobedo FJ, Wagner JE, Nowak DJ. Analyzing the cost effectiveness of Santiago, Chile's policy of using urban forest to improve air quality. Journal of Environmental Management. 2008;86:148-157.

3. Garg SS, Kumar N, Das G. Effects of the Bansal Ramraj Mill Dust on Vegetation and Health at Jaitwara, District Satna (M.P.). Indian Journal of Environmental Protection 2000;20(5):326-328.

4. Manins P, Allan R, Beer T, Freaser P, Holper P, Suppiah $\mathrm{R}$ et al. Atmosphere. Australia State of the Environment Report (Theme Report). Commonwealth Scientific and Industrial Research Organization (CSIRO) Publications. Melbourne 2001.

5. Prajapati SK, Tripathi BD. Seasonal variation of leaf dust accumulation and pigment content in plant species exposed to urban particulates pollution. Journal of Environmental Quality 2008;37:865-870.

6. Prusty BA, Mishra PC, Azeez PA. Dust accumulation and leaf pigment content in vegetation near the national highway at Sambalpur Orissa, India. Ecotoxicological Environmental Safety 2003;60:228-235.

7. Rangkuti MN. Kemampuan menyerap timbel $(\mathrm{Pb})$ pada daun beberapa jenis tanaman penghijauan jalan tol Jagorawi: Analisis struktur anatomi dan histokimia [Thesis]. Bogor: Bogor Agricultural University 2003.
8. Rao DN. Sulphur dioxide pollution versus plant injury with special reference to fumigation and precipitation, in Proceedings of the Symposium on Air Pollution Control. Indian Association for Air Pollution Control, New Delhi. India 1983;1:91-96.

9. Rawat JS, Banerjee SP. Urban forestry for improvement of environment. Journal of Energy Environmental Monitoring 1996;12:109-116.

10. Shukla S, Sharma RB, Sahu M. Research Article Dust Pollution Affect Morphophysiological traits of Plant Mangifera indica Linn. International Journal of Botany 2019;15:1- 4.

11. Spatt PD, Miller C. Growth conditions and vitality of Sphagnum in a tundra community along the Alaska pipeline haul road. Arctic 1981;34(1):48-54.

12. Vora AB, Bhatnagar AR. Comparative study of dust fall on the leaves in high pollution and low pollution areas of Ahmadabad. Journal of Environmental Biology 1986;7(3):155-163. 